\title{
The Information Seeking Behavior of Digital Native and Digital Immigrant Students of Bogor Agricultural University
}

\author{
Janti Gristinawati Sujana ${ }^{1 *}$, Pudji Muljono², Djuara P. Lubis ${ }^{3}$, Sulistyo-Basuki ${ }^{4}$ \\ 1,2,3 Department of Communication Science and Community Development, Bogor Agricultural University, Indonesia \\ ${ }^{4}$ Department of Library Science, University of Indonesia, Indonesia
}

\begin{tabular}{l} 
Article Info \\
\hline Article history: \\
Received Dec 3, 2017 \\
Revised Jan 16, 2018 \\
Accepted Jan 23, 2018 \\
\hline Keywords: \\
Bogor agricultural university \\
Digital immigrant students \\
Digital native students \\
Information seeking behavior
\end{tabular}

\begin{abstract}
Technological expansion and the changing way individuals gain access to information has deeply impacted the structure of libraries - physically as well as conceptually. A new generation of digital services platforms for libraries is emerging, designed to provide a more comprehensive approach to the management and access to all formats of library materials. Despite the modernization of libraries and their adaption to the digital age, the library still hold a critical role within community to serve its users, continuing to be beacons of information sharing, learning, and entertainment even amidst tight fiscal times.As one of the leading university in Indonesia, Bogor Agricultural University Library must find solutions to new challenges, overhaul many of their entrenched business processes, and foster systems that engage students.This study examined the information seeking behavior of the digital native and digital immigrant students of Bogor Agricultural University, in order to remind the library that there are some changes happened in its users and to recommend the new services should be taken by the library. The similarities and differences in seeking information of those two group students were discussed.
\end{abstract}

Copyright $(2018$ Institute of Advanced Engineering and Science. All rights reserved.

\section{Corresponding Author:}

Janti Gristinawati Sujana,

Department of Communication Science and Community Development,

Faculty of Human Ecology, Bogor Agricultural University,

Kampus IPB Darmaga, Bogor 16680, Indonesia.

Email: jantigs@gmail.com

\section{INTRODUCTION}

In the process of learning the students must be supported by appropriate information, they should not rely to the knowledge they had gained from the lectures. They must acquire additional knowledge by reading books, proceedings, research reports and journals. When they have to write papers, they are required to read a lot of various sources of information. Especially when students have to do research for the final project, students should look for various research results that show the state of the art problem to be studied. Thus it is imperative for a student to seek information.

Today young generation is very expert in using various means of information and communication technology. It should be asked whether the younger generation then become an expert in finding information. [1] reported his study on the information seeking behavior of the Net Generation. The results of this study indicated that members of Net Generation may understand technology, meaning they are confident and tend to use technology. However, they clearly do not have the information literacy capability. They can not search, prove the truth, make meaning and use information effectively or efficiently from a series of electronic sources. They are easily satisfied with the first information they encounter, believe in search engine results and instantly retrieve information obtained, little or no reading or interpreting search results.

Information and communication technology (ICT) has been growing quickly these days, the entire education framework has to be improved and ICT must be coordinated into school activities. There is a huge 
impact of the internet on students' lives. The existence of the internet with abundant information, makes some people think the library is not needed anymore. By accessing the internet, everything is there. However, research proves that the internet is not the answer of all information needs, because people who use the internet must have certain skills to be able to utilize the sources of information on the internet. Some research results prove it.

Van Deursen et al. [2] reported their study on internet skills which was connected to other several variables. The study was conducted on four groups of respondents aged 18-29, 30-39, 40-54, and 55-80. Frequently presented statements that people learn internet skills better directly practice, through trial and error, than through formal education. This study proves that the statement is true for operational and formal internet skills, but not for information and strategic skills. Internet skills have a weak relationship with the length of internet experience and the amount of time spent online per week. Similarly, content-related skills are unrelated to the length of internet experience and the number of hours spent online per week. With regard to information skills and strategic internet more relevant relate to the attainment of education level, as it relates to intellectual skills.

Zimerman [3] conducted an experiment to investigate the best practices of information seeking behavior of students to clarify whether they were digital native or immigrant. The survey respondents who are 31 years or under were considered as millenials, whereas those who are above that age were considered non-millennial. The Zimerman's research concluded that libraries and schools should adapt to digital native habits. Digital natives access information through a variety of ways, via broadband such as smartphones, as well as small electronic devices that are connected either to high-speed telephone lines or the internet. There is some evidence that the age group of millennials mostly uses web services, including Google, Wikipedia and school electronic databases, while respondents from other age groups do not often use those resources. Further questions were asked to know whether searching on Google will provide the required scientific materials for a college assignment, the respondents stated possible. Most respondents of the experiment expressed that some articles they required were obtained by through Google, however specific data they required were not available. Searching through Google will bring tens of thousands of answers that are difficult to reduce. Finally the respondents answered that utilizing Boolean logic and subject headings for searching the information through their schools' databases available in the library, provided more specific and accurate results. Thus the required information were quickly found to supports their assignments.

Malliari et al. [4] distributed questionnaires for 13 (thirteen) study programs' students of the graduate school inthe University of Macedonia, Greece. The results show that in order to identify and rediscover the relevant information, most graduate students use the simplest techniques. More than $50 \%$ of respondents felt that they were experts in searching the web,and competent in tracking various scientific databases and/or electronic journals. However, the results of the study shows the respondents' information literacy skills, the way they use information and evaluate does not indicate a high level of skill. They often thought their search competencies higher than they really were.

Previous researches revealed that the information are abundance, but information users are not ready to utilize those information effectively and efficiently. What action do librarians need to take to ensure that libraries continue to be relevant in today's modern society? It's time to stop talking about the dismantling of library services and instead to demand action, to bridge the gap between where the role of the library today can be focused. The human element is no doubt critical to the future success of the libraries, through library professionals who operate on the 'front-line' to deliver services that engage, inform and unite the local community. The librarians have to be aware that nowadays the library is not the only source of information for its users, but the library should still be a guide for users in searching for information. The library should be leveraged and strategically used for the students' learning. This studys ought to establish the information needs of both the undergraduate and graduate students, whether they are digital native and digital immigrant users of Bogor Agricultural University (Institut Pertanian Bogor) library.In addition, the study furthers ought to understand the impact of the introduction of new technology on users' information-seeking behavior. Understanding the behavior of seeking information from those users, enable the university library to prepare services needed by the users. According to [5], "information seeking is a concious effort to acquire information in response to a need or gap in your knowledge." Wilson in his dissertation published in 1971 has led to an information behavior model, which was then published in 1981. In order to satisfy the need, the model suggest that the user makes demands upon formal or informal information sources which result in success or failure in information seeking process. If successful, the individual then makes use of the information found and may either fully or partially satisfy the perceived need or, indeed, fail to satisfy the need and have to repeat the search process. The model also shows that information seeking behavior may involve others through information exchange [6].

This research aim to investigate the information seeking behavior of students Bogor Agricultural University, whether they aredigital native and digital immigrant generation. Although this research involved 
the limited students in focused group discussion, the result of this research will describe something new going on the academic library users. It will also give strategic inputs for the development of the Bogor Agricultural University Library. The result of this study will also remind the Indonesian librarians that the libraries are facing the continuos changing as the impacts of the ICT developments.

\section{RESEARCH METHOD}

This research is a qualitative research, with descriptive approach. Data collection for this study utilized Focused Group Discussion (FGD). Focused Group Discussion (FGD) is a process of collecting data and information systematically on a particular problem that is very specific through group discussion [7]. FGD was utilized twice for this study.The first FGD, was carried out to assess students inthe digital native generation, and the second FGD was to assess students from the digital immigrant generation. Determination of the digital native and digital immigrant generation follows the Indonesian Internet Service Providers Association's provisions during an internet users survey in Indonesia in 2014, that the native digital group is aged 13-25 years [8]. Thus the digital immigrant group is over 25 years old.

Data of IPB students were obtained from Directorate of Education Administration, and Directorate of IPB Diploma Program. They show that both the undergraduate and diploma program students are under 25 years old. While students of Graduate School $34.71 \%$ are digital native students, and $65.29 \%$ are digital immigrant students.

It was planned that each FGD group was consisted of 7 (seven) to 10 (ten) participants. The studentparticipants were invited through an announcement in the library and librarie's web. The criteria for selection for students to be qualified for grouping was their age.

Although at the time of registration 10 (ten) students in each group of Focused Group Discussion were obtained, the time of the FGD implementation only 7 (seven) students came. According to [7] the ideal FGD participants will be between 7-11 students. In the FGD digital native group, 6 (six) students were from the Undergraduate Program and 1 (one) student was from the Graduate Program. While for the digital immigrant group, theparticipants were from the Graduate Program, five out of them are students of master degree program and two of them are students of the doctoral program.

\section{RESULTS AND ANALYSIS}

The Focused Group Discussion was well-implemented. No participant was toodominant for thediscussion or passive. Although the participants are fellow students of IPB, but they didnot know each other. As the FGD participants were from different course of study, thus they were really conducive for better for the conclusion. Thus, the conclusions would not be applicable for specific courses of study, although this study is not intended for generalization.

According to [9], the main purpose of Focus Group Discussion is to get as much information about a theme as the focus of research. The main theme of this research is the information seeking behavior of students, which is distinguished between students of the digital native generation and students of the digital immigrant generation. Discussion of research results are differentiated by digital native group and digital immigrant group on each discussion topic. To clarify the delivery of FGD results, FGD participants are named with the code, Mhs A is for FGD participants from digital native groups and Mhs B are FGD participants from digital immigrant groups. Then the participants are given the serial number, so it will be seen clearly a statement given by certain participants.

\subsection{Digital Native}

\subsubsection{First Step in Finding Information}

The study was designed to explain when a student has some information need, what is the first information source s/he is looking for. It becomes a marker that the source of information that is trusted by students will provide problem solving in the information needs. Many people do not think of the library as the first place to get their information.

Out of the seven participants, five of them stated they directly use the internet to find the required information. Not all of them start their information seeking process using the Google search engine, some are starting from social media like Facebook and Twitter. If they fail to get the information they need from those social media, they then will move to Google. On the average they ask their friends if they do not find the information they are looking for on the internet.

"If I need information I browse Google the first sources for quick sources, Ma'am, then looking for internet sources, well if I'm stuck I'll consult friends. I can limit or even reduce the 
use of social media, as they are less interested for me, I prefer to have face to face encounters with friends" (Mhs A6)

There are two participants who still use the library for their information needs.

"When I need information for thesis and papers writing, I go to the library and I read the thesis related to my subject. Then I check the references of the thesis whether there are titles related to my subject, then I search those titles from the online journals available in the library. In addition journal articles I also look for books for additional information" (Mhs A5)

"For me, Ma'am, I will seek information if I planned to write a paper or article. First I will try to search or browsing on Google. If I can not get the information I need, then I usually go to the library to consult some undergraduate theses or books. I will use the retrieved articles as reference materials for my proposed articles. If I found difficulties, I'll consult friends or the lecturer"' (Mhs A4)

\subsubsection{Parties Who Help to Seek Information}

All participants said their friends played important role in helping them to get information even though they are from different courses, none of them mentioned librarians. They might be in the similar cohort, classmate, have similar thesis supervisors, colleagues in the same department. The amount of information obtained from friends are higher, as the intensity of communication among friends is higher. Moreover, as some books or journals they use are already in electronic format, they can share their books or journal articles to their friends. Some say that they gets a lot of information from their seniors, as they are more experienced, they can assist the juniors to find literature that is relevant to juniors' research, the books should be read and the relevant journal addresses to be accessed.

"For me, my helpful friend assist me to get the information I need, but for scientific information I usually consult to my senior, I often ask where to find a certain literature. Senior must know better because they are more experienced, they will later tell what kind of books to read, the most important journals will be available online" (Mhs A7)

Five out of the seven participants, mentioned that the lecturer played important role to assist them to find the required books, relevant journal websites, and some even tell the keywords used to seek information. A participant mentioned that the lecturer who is familiar with the students usually tells them in detail where to find the information they need. Another participant mentioned that related to research program he carried out, his supervisor play important role to help him to get information to support his project. But there are also students who rely on electronic information sources only, rather than the friends assistance.

\subsubsection{Utilization of Information and Communication Technology}

All participants felt they are highly dependence on information and communication technology (ICT). Laptops are always taken, often come to the library because they want to take advantage of Wi-Fi. In places where there is no Wi-Fi they do tethering hotspots from smartphones. Mhs A2 said that he is very dependence on information and communication technology, as utilizing ICT it is very quick and easy to find information. Mhs A2 prefer to use the phone because of its small size, so easy to carry it. According to Mhs A1 and Mhs A4 about 75 - 100\% of students are highly dependent on information and communication technology. The high dependence of young people is described as the following Mhs A3.

"Our generation is the millennial generation - we think it's really technology, Information and Communication Technologies (ICTs) have infiltrated our daily lives. We're truly in a connected world. Our smartphone is not only the first thing we turn to in the morning, but the last thing we check at night. It's really Hi Tech era, so we really need gadget.The phone or tablet is probably the first thing we look at in the morning and the last thing we look at before bed. Young people wake up with their smartphones. Definitely we need this technology, coupled with the internet. Rather than going to a library to check out a book, the digital systems allow people to get ebooks from every where. Most information is found on the internet by utilizing search engines. We may say that the increasing use of the internet has been a good influence in the realms of education, personal relationships and the economy" 
Although the utilization of ICT is very high, but the research found that Mhs A6 still prefer the print format rather than to electronic, as she can write some notes on the information sheet.

\title{
3.1.4. Utilization of Social Media
}

The young generation is definitely not free from social media. Amid it all, one thing is clear, various types of social media in all of its forms has definitely become an integral part of life for Bogor Agricultural University students. Six out seven students, mentioned that WhatsApp and LINE, are the dominant mobile messaging app among students of Bogor Agricultural University. Mhs A3 stated that he uses WhatsApp, also Path and Instagram, but he does not use LINE. One of the factors that influences the use of certain social media is friends in the environment. Mhs A1 stated when he returns to his home town, he uses Blackberry Messenger (BBM) as an instant messaging application because most his friends in his home town use BBM.

Facebook and Telegram are other social media used among students of Bogor Agricultural University students. Mhs A4, Mhs A5, Mhs A6 and Mhs A7 stated that to engage with peers they prefer to use LINE, but for communication with their senior students and their lecturers they use WhatsApp. They decided to use LINE as it has more features, they can even take part in group phone calls, it looks more attractive and cool.

\begin{abstract}
"For me, my first choice LINE. Some groups of my class mates use LINE. It seems that generational differences affect the use of different social media. Senior students mostly use WhatsApp. Why we use LINE, I do not know exactly the reason why we use LINE social media. Probably because it is more comfortable, Ma'am. It has a lot of stickers" (Mhs A4)
\end{abstract}

\subsubsection{Utilization of Web 2.0 Technology}

According to [10], "Web 2.0 technologies are a simple and effective platform for organizational to collaborate, network and interact with stakeholders". Included in Web 2.0 technologies among others are blogs, wikis and YouTube.

All participants have personal blogs, but most of them do not update their blogs, because they are busy attending class activities. According to Mhs A6 almost all IPB students have personal blogs as the university provides facilities to create blogs in the campus. Only one out the seven participants, who is the active to update his blog when he spend his holiday, the other do not open their blogs. Mhs A3 did not like to open her personal blog after she has no more classes, because she had created a personal blog as it was required by some courses she took. At that time she must upload her class assignments on the blog with the aim her colleagues to read and comment on each other's work.

YouTube nowadays not only loads entertainment videos, but also a lot of scientific videos. Therefore, many participants use video to view application tutorials softwares, short films on social issues, explanation on research methods, and so on. Mhs A5 said that it is easier to understand a tutorial using video than through printed articles. But most of the participants access YouTube as their entertainment, some even said that if they seek scientific information they do not access to YouTube. One of the participant made statements on the use of YouTube as follows.

"For the scientific materials I access YouTube, I often see tutorials such as Eviews, how to apply the research methods on YouTube. Sometimes also if confused in applying Excel, then I found the tutorial explaining to apply Excel in YouTube. For entertainment, I also go to YouTube, I can see many variety of music" (Mhs A3)

\subsubsection{Utilization of Bogor Agricultural University Library}

A major challenge facing today's libraries is to develop and update both traditional and digital collections and services to meet the needs of the multiple generations of users with differing approaches to information seeking. Earlier, students came to the library just to borrow books, but nowadays students come to the library do not only to check out books, but for other purposes. Mhs A1, Mhs A2, and Mhs A5 come to the library because it is quiet and comfortable place for study, so they can concentrate their minds to the subjects they learn. Mhs A2 has become frequent visitor to the library by the time he implemented his research project. In the library he can discuss with his friends, as the library provide the facilities. For Mhs A5 who is in the process of finalizing his thesis, other than convenient the library also enable his seeking the information easier to support his thesis.

Wi-Fi access is now available in the Bogor Agricultural University (BAU) library, it has made the library the favorite place for students to visit. In addition, the thesis / dissertation collection is also one of the goals for students to visit the library, especially for students who do not like the access digitalized thesis / dissertations collection accessible on repository.ipb.ac.id. 
Related to books collection of the library, Mhs A1 has never looked for books in the library, he usually borrowed many books from his colleagues, or searching for free electronic books in the internet. Likewise, Mhs A2 does not know the availability of books for his courses in the library, he has never heard or utilized the library catalog. However Mhs A4 is still the active member of the library, she often come to the library for books she needs, because not all the required books for her courses are available on the internet. In addition her lecturer often recommends her to find books in the library. Frankly speaking, she is the active patron of library for books. Mhs A5 answered that he also often borrows books in the library. Similarly, Mhs A6 was still seeking books in the library for her courses. She does not like using electronic books, but she prefers the printed ones. Novels collection is one of popular collection and it is the favorite leisure reading materials for students. Mhs A4 and Mhs A6 like borrowing novels from the library.

\subsubsection{Problem in Seeking the Information}

This research tried to investigate the information seeking behavior of student Bogor Agricultural University, whether they are digital native and digital immigrant generation. In addition, the research will also tried to find out problems are faced by student when they are looking for information. Of the seven participants, three participants found difficulties with the English language. Some say that English for scientific information is more difficult to understand. Using an interpretation application the results are not accurate. For books in Indonesian are still lacking for certain fields of science, such as on agricultural technology.

Another dominant problem experienced by the participants was the difficulty of obtaining the required books in the Library. Similar statement was agreed by the other three participants. However, two participants stated that the books they sought were old version.

"I found difficulties to get a book in the BAU library. I needed old version of books, for my course let's say books published on 1998, they were not available anymore in this library. They were really required to support my research project, as references. Where should I look for them if they are not available in the library, they even no longer available in the bookstores" (Mhs A3)

Confession made by one of the participant, he stated that searching for information using Google takes a longer time to filter out irrelevant information. Then another participant said that the information he got from the internet sometimes was really confusing due to the different information from various sources for information.

\subsubsection{Expectation for Bogor Agricultural University Library}

A lot of expectations were expressed by students to the library to improve its services.In terms of technology a participant expected that the library to continue to upgrade the technology used. The library room is now quite comfortable, but students expected that the interior should be renovated into with a minimalist design.In addition to comfortable situation, one of participants hopes that the quite atmosphere also needs to be maintained because sometimes the library is very crowded.

Four FGD participants expected that the acquisition systems for bookand other library collections development must be improved, more titles related to their subject interest must be acquired for BAU library.Mhs A3 suggested that old books must also be acquired for her needs. Mhs A5 feels that the BAU library lacks of electronic journals on the other subjects, particularly his subject interest. Compare to CIFOR's electronic journals collections, IPB library collections is less. He doubtsthe quality of journals available free.

As current students always use computers or laptops, then suggestions related to ICT development are plenty. Four participants suggested the need for additional computers in the library for students uses. Then, additional electric outlets in most spaces in the library, as some even do not working. Four participants complained about the slow Wi-Fi in the Library, whereas students often need access to the internet. The last but not the least, a participant hopes the library staff must be courteous and more friendly, so that students would not be afraid to approach them for consultations.

\subsection{Digital Immigrant}

\subsubsection{First Step in Finding Information}

When they need information on books and electronic journals, almost all participants of this FGD said they immediately search for information in the internet. Only after they knew that the book or articles they searched are not accessible in the internet, they then searched the books they needed into the library. One of the participants stated that he did not search in the internet as his seniors will provide electronic books 
as listed in the syllabus of the subject he enrolled. Likewise, other friends who are alumni of BAU (whom his/her undergraduate program was also from BAU) usually informed him list of references utilized by lecturers when they took similar subjects.

"My personal experience, so far online is the best way to search the needed information. Just related to my own subject interest on agricultural engineering, I sometimes have to learn other information any kind of technology, the most modern one which are currently developed abroad, for visualize performance YouTube is the answer, very helpful” (Mhs B6)

Another participant stated that sometimes she got electronic book from her lecturer, and electronic journal from the Faculty library. She also likes to search information in eLearning videos, which can be a very powerful learning tool, as they add a dynamic element to the eLearning courses, improve knowledge transfer, demonstrate complex procedures, and help explain difficult topics. But they understand that they learn theories or principles of their subject from the text books, whereas for updated information they seek them in the journal. Mhs B5 sometimes consult directly to the expert of the subject she learns, especially her lecturer.

"When I need information I search in the online journals and books. Indeed books are for basic science, I mean scientific principles. Online searching usually more for journal articles, Ma'am, as journal contains current information" (Mhs B2)

\subsubsection{Parties Who Help to Seek Information}

Five participants stated that the first person to be contacted when they are searching for information was a friend, classmate in the study program, a cohort mate, fellow in the study program, one class companion, and fellow from the same department. Two participants stated they like to try to search information on the internet, one started from Google Scholar, while the other through the BAU repository. All participants stated that lecturers often recommend reading materials consisted of books or journals, some even distributed electronic books directly, or suggested to consult his student for a publication he listed as supervisor. One participant mentioned that she also adviced to search for information from certain books or journals from the laboratory technician.

Various methods of information seeking were stated by FGD participants. Some also utilized the bibliography of publications to search for information they required. One participant said she went to other library outside BAU which is noted for strong collection for its particular field. A participant even asked a journal article to a friend who was studying abroad. So various methods on information seeking behavior of students were explained. Only one participant mentioned the library, and it was the library outside BAU.

\subsubsection{Utilization of Information and Communication Technology}

In this digital era people's dependence on information and communication technology is very high. Likewise with FGD participants who in term of their age, they belong to digital immigrant, all of them stated that they are very dependent on information and communication technology. Mhs B1 needed information and communication technology for searching digital journals. But she feels that she does not belong to a group of a very addicted with information and communication technology. She always takes her laptop to campus, as all of her works are in her laptop.

All the other participants also agreed that the use of information and communication technology, especially the internet, have greatly helped them in solving their academic problems, to communicate with lecturers, friends, and to obtain academic announcements from departmental administration. All of them were carried out through their smartphones. Mhs B4 tried to brake her dependence on the internet, by not refilling the data packet that has been exhausted, on her mobile phone.

"I wanted to break my dependence on internet access, usually in the boarding house, while having my meals I try to read some article. I wanted to be isolated from the internet withina week. The positive side of this method, I really feel refreshed, but on the other side I had been worry as I might miss important information, thus I left a week behind" (Mhs B4)

In addition to academic and communication activities, the internet can also be utilized assource of entertainment when most classes are reses, and there is no TV set in the boarding house.Internet has been other source of entertainment for Mhs B3 as through one of the ICT media enables her to download movies from the internet. On the other hand, the internet makes people look like getting together, but actually each 
person is busy with his/her own business. Increasing reliance on the internet may also reduce actual social interaction and/or hinder social abilities. Mhs B4 and Mhs B6 agreed with her.

\subsubsection{Utilization of Social Media}

The use of social media depends on friends around him/her. Someone can have more than one profile on social media. For example Mhs B1 uses LINE because some of her friends use LINE. On campus she uses WhatsApp more because she has a lot to do with her seniorswho mostly use WhatsApp. Some friends suggested to use Instagram and Path, but she refused because she felt too much social media.

WhatsApp is used by all FGD participants, and according to Mhs B3 for most academic activities using WhatsApp, both for communicating with friends and with lecturers. LINE as social media is used by three participants among the FGD participants,Facebook is used by six participants, Twitter is used by two participants, Instagram is used by four participants, no FGD participants use Path, two participants using telegram related to their personal interests, and Blackberry Messenger is used by five participants.

\subsubsection{Utilization of Web 2.0 Technology}

Four out of the seven participants have individual blogs, but the owners rarely update their blogs lately. Two bloggers said that a blog is also a good way to keep track of articles on a site. For a personal blog, you might have a bunch of observations, or reviews. Mhs B2 said that a blog would be her media to write. However, she recently changed to write on Facebook. According to Mhs B2 bloggers write about niche based topics not genre like traditional publishers. This means their audience is super targeted and when you find bloggers who align with your product or service niche, through the blogger you are reaching many people who actually do want to hear about your brand. Similar to the opinion of Mhs B7, that actively writing on the blog can be added value for him, especially when he had to join the special competition. According to Mhs B3 it was her pleasure to write on the blog, especially when her audience, High School students, trusts her recommendation and will take them as reference and marked with "LIKE" on her blog acknowledged her.The pleasure to write on the blog was expressed by Mhs B7 as follows:

"My hobby is more towards social, travelling is more than just a holiday plan for me therefore I started my travel blog journey. I decided to start writing my own stories and documenting my own adventures. I am very happy to write on the blog because it becomes a pride in my own work, for example when I upload the posts many people like it, and they are writing some comments. Posting a question about your post will give them an anchor point to what they can talk about. Some readers usually give their input, some readers will appreciate my post”"

Mhs B5 does not have any blog, and she does not want to read someone's blog carelessly. She must understand and know the owner of the blog, because she has a serious doubt to look at the posts of unknown blogger. But for Mhs B6 she has different experiences related to individual blogs. She likes to find posts on someone's blog that provide easier to decipher meaning and comprehend the language, but she thoughtwe need to be careful with phrasing here, the posts on individual blogs for its accuracy of the information.

Regarding the use of YouTube, it had been partially discussed in the early part about the digital immigrant students. There had been participants who think that the video on YouTube can help her understand how a tool works, especially if the technology used by the tool is still unfamiliar for her. The opinion of another participant that the material on YouTube is usually a mass communication, while the new invented materials have not been display on YouTube. She has to look for it in the journal.

\subsubsection{Utilization of Bogor Agricultural University Library}

Is the library abandoned by its users? Though all FGD participants are highly dependent on the internet, however they think that they still need libraries. As stated by Mhs B4 that to understand more on the theories of the disciplines she learns, she prefers to read books in the library rather than through internet. Accordingly, Mhs B3 will search the old books to the library. She feels there is a specific chemistry in the library. When she gets difficulty for the book she searched, she then approached the librarian for assistance, and she was happy when the book could be located by the librarian. She thought that the librarians are knowledgeable to assist the users, so they will locate the books they search easily. Even when Mhs B3 has currently completed most of her subjects, but she will come to the library to use internet. She used to download movies from the internet for entertainment while she had no assignment from the lecturer.

Although nowadays, online businesses always seem to know what we want, however according to Mhs B2 it has its limitations. For example, limited with its smartphones, with its laptops, and internet connection problems as it can be frustrating. Therefore, the library with its books would not become obsolete during the lifetimes. She herself preferred to use printed books instead of electronic books. 
In general, the BAU library is comfortable, fun, quiet, very supportive for students to learn. The statement was stated by Mhs B1, Mhs B2 and Mhs B5, although according to Mhs B2 when more and more users come into the library, they cause hot inside. Mhs B6 often uses the Faculty library, because the librarian in this library assists her to get the journals she needs.

\subsubsection{Problems in Seeking the Information}

All participants complain about journals they need are not available for free, and if you have to buy the price of the articles are very expensive for a student. There are also channels where they can access paid journals for free, but there are still restrictions. The students usually need journal articles in large numbers, because the papers they have to write a lot, and one paper could need about 20 titles of journal articles.

Another complain from many FGD participants is the language of journal articles they must read. Six out the seven FGD participants, complained about the language. According to some participants, for a graduate student whose undergraduate program was from outsideBAU has more difficulty in reading English-language journals. It takes a longer time to comprehend the journals. Not to mention the backwardness of existing technology in Indonesia, making them more difficult to understand the journal. According to Mhs B5 if the technology in Indonesia is developed, and there are some journal articles discuss about the technology in Indonesian language, it would be easier for her to understand the English article by comparing with the Indonesian article.In addition to English articles, some FGD participants also encountered many language problems as they are printed inFrench, Portuguese, and others.

Internet connection is also another problems complained by six FGD participants. Usually after 12 noon the internet connection via the Wi-Fi network connectivity ofthe library is slow. Mhs B6 saidshe had to wait for hours to be able to access to the internet network, sometimes even a day she was unable to connect into the internet via Wi-Fi network connectivity of the library. Mhs B2 prefers to use her smartphone to access the internet. The slow access to the internet is not only happening in the library, but also in the departmental environment. Mhs B7 often come to the library area at 9 pm until morning to get a fast connection to the internet.

"We are unable to connect the internet as there is no internet network in our department. It causes a lot of problem for us. We have to find other spots in order to connect into Wi-Fi network connectivity. Therefore we go to the library, but similar problem also occur there, after 12 o'clock the internet speed is very slow. Because I am a man, I took initiative to go to the library at nine o'clock at night until morning to access the internet"(Mhs B7)

\subsubsection{Expectation for Bogor Agricultural University Library}

It is obvious that in the digital era connection to the internet is very important. Of the seven FGD participants, six participants complained about slow wireless internet browsing and intermittent connections in the BAU library, they are really required to support their classes assignments. According to the observations of Mhs B1, for group of students under 25 years, digital literacy is not problem for them, they can quickly operatethe various systems available. While for group of students from the doctoral program who falls into group above 25 years (elderly groups), they experience difficulties to access electronic journals. It is expected that BAU library will provide special trainings to provide technical knowledge in utilizing computer for accessing electronic journals.

Three FGD participants complained about the availability of contact sockets in the library, as some of the outlets are not connected to electric currents. Since they are heavily dependent on the utilization of laptops, then plugs into electricity becomes very important. Although we are now in the digital era, however according to Mhs B5 printed journals are still required. Even Mhs B6 expected that both online and printed journals must be subscribed, to enable them read both the online as well as the printed article of thejournal in the library. In addition, a participant recommend that BAU Library should subscribespopular quality journals on economic, political, social and cultural aspects, to update their general knowledge for refreshing.

As required by BAU that students of the graduate studies have to send their scientific articles for both local and international journals, Mhs B5 expected that the BAU library will publish list of blacklisted publishers, to enable students select reliable publishers for their proposed articles.Another participant, Mhs B3, expected that the library will publish list of national and international journals which are indexed in the SCOPUS database, as well as accredited journals by the Directorate General of Higher Education, the Ministry of Research, Technology and Higher Education, and the Indonesian Institute of Sciences. The participants expected highly that BAU library inform list of address of free journals. One participant recommend that BAU library acquired updated version of books in the collection, but suggested retain the old one which be needed later. In addition, he recommended that the Library will display newly acquired books in the display case.

The Information Seeking Behavior of Digital Native and Digital Immigrant... (Janti Gristinawati Sujana) 
An FGD participant wanted that the library organize special seminars or training courses on writing techniques, of book reviewing. Once in a while the library should also invite author of scientific book to promote the book. Such training courses or seminars will improve the soft-skills of students for their future, said Mhs B2.

"Any event organized by BAU library, such as small seminars on any topic, such as inviting book author, or book review, writing techniques for popular books or journal articleswill be important for students as their leisure time, not only learning in the classes"

In this digital era people's dependence on information and communication technology is very high, especially for the internet access for bothdigital native and digital immigrant students is similar, although efforts were made by digital immigrant students to control themselves to reduce that dependency. There is an awareness of digital immigrant participants that in this digital era people seem to be together, but actually engrossed in their own world. Internet and mobile technology seems to be subtly destroying the meaningfulness of interactions we have with others, disconnecting us from the world around us, and leading to an imminent sense of isolation in today's society. The study also shows that the first time that digital native and digital immigrant students do when they need information is searchingthrough the internet. Indeed after that there are also looking for books, theses, dissertations and journals to the library. The availability of fast internet connections is a major requirement of library users today, so libraries should strive to gain substantial bandwidth allocations.

Parties who help digital FGD participants natively seek information in general are their friends, as [11] says one of the characters of the internet generation is "a generation that relies on collaboration and relationships". However, in digital immigrant participants it is also the same that helps them find information is friends. This may be because the digital immigrant FGD participants are young as well. Most say that lecturers also help them to show the sources of information. [12] Research in distance students from the University of London aged over 25 from 81 countries shows that lecturers play a very important role in the information seeking behavior of these remote students. As for undergraduate students, they often use relatives and friends as a source of information. Even a student says "it's easier to get information from friends rather than from the library". Therefore, the BAU library should use students as its extension services to provides library use education to equip users with knowledge. This will enable the user to use the library resources effectively and efficiently. Lecturers should also be informed continuously on the current situation of the BAU library, so they will be able torecommend the needed information to students.

Social media used is usually determined by friends in the neighborhood. LINE, WhatsApp and Facebook are social media that are widely used by FGD participants. LINE is primarily used by the digital native generation and WhatsApp is primarily used by digital immigrant participants. Blackberry Messenger is still quite widely used because old friends before they become BAU's students still use BBM. Twitter, Instagram and Telegram are used by a small number of participants. The path is only used by an FGD participant. Librarians should learn how to use various social media utilized by students, to enable them communicatewith students smoothly.

All participants have personal blogs, but most of them do not have the time to updatetheir blogs. The pleasure of writing on the blog was encountered in FGD digital immigrant participants, probably because their ability to write was more qualified. Not only is it fun to be an "expert" on a topic, it could lead to people looking to you for your opinion on a recent event in your niche. All participants realized the need to carefully select the information from individual blogs. YouTube is no longer a source ofinformation solely for entertainment. Digital native participants use YouTube for tutorials applications, explanations of research methods, and so on. Participants from digital immigrant use YouTube to see how a tool or technology works, learning something from YouTube is easier.

Library utilization by participants of both digital native and digital immigrant is still quite high, however not all digital native participants are familiar on the use of library. Some even have never been to library, never known about library collection and how to use them. The data show that the library use education program for new students has not been effective. Some new students might miss such important "introduction of the library program" due to the limited time provided for them.

Still quite a lot of digital immigrant who are looking for books to the library. Foreign language barriers are the most common barriers for BAU library users in utilizing library collections as plenty of books are in English, and some of them in French, Portuguese, and others. [13] Mentions that one of the obstacles in finding information is a language problem. Thus it is suggested to the English lecturer to organize special discussion on how to effectively read English literature. The library has also suggested to organize special workshops on reading English literature effectively and efficiently. 
Many of the expectations are presented by FGD participants, whether from digital native participants or digital immigrant. In particular, they hope the speed of internet access is improved, the facility for electrical outlet such as contact sockets must be multiplied, the acquisition of book collection needs to be increased, and the old edition such books must be also provided in the library. The list of journals subscribed must be enlarged, and if possible both the online as well as the print version. Quality popular journal needs to be subscribed. The librarians are expected to help the students in submitting their research articles to the required journals as one of the graduation requirements in BAU. The library's role has changed, not just providing and lending books, as well as tracking information. Libraries continue to remain relevant in our lives. The challenge is not only to have a large quantity of material but also to make it available to people, otherwise libraries will be abandoned by its users.

\section{CONCLUSION}

In utilizing information and communication technology, there is no significant difference between the participants of the digital native and digital immigrant students. There is only a feeling for self-control in using ICT on digital immigrant participants. With regard to library utilization, digital native participants have a tendency to come to the library to get internet access only, while digital immigrant participants are aware that if looking for the theories or basic principles of their disciplines they have to read books, and get the books from the library.

Friendship among students is very positive, because they share the information they need. Provision of information is facilitated by the format of electronic information. Social media is widely used LINE for digital native students, and WhatsApp for digital immigrant students. You Tube is no longer solely a source of entertainment, but also a source of knowledge. In general, the basic information literacy knowledge of the FGD participants are good enough for both digital native and digital immigrant students. They already have the caution in using information sources. However, they still need to be equipped with more information literacy skills such as the copyright of electronic documents.

\section{RECOMMENDATION}

To respond the needs of students to access the internet, Bogor Agricultural University Library should increase its bandwidth into the wider ones the library areas. Related to the accessed materials, more title of electronic journal must be subscribed, as not all information needs are currently being met. In addition, the collection of books needs to be constantly updated, both in printed and digital format, despite of acquiring the new edition of publications however the old addition must be also provided in the library. Another choice, when the old version is required interlibrary loan system must be established to meet the user's needs.

Bogor Agricultural University Library should provide unconventional services, such as disseminating appropriate journal titles for students who plan to publish their research articles, announce the blacklisted journals, and so on. In order to improve the dissemination of library information BAU Library should cooperate with students, considering the communication among students are smoother and better. Supplying information to the lecturers is also a good way to make the utilization of the library more optimum. Information literacy training should be provided although the students are already have the caution in finding information.

\section{REFERENCES}

[1] B. Combes, "Digital native or digital refugees? Why we have failed Gen Y?," in Proceedings of 38th Annual Conference of the International Association of School Librarianship incorporating the 13th International Forum on Research in School Librarianship: Preparing Pupils and Students for the Future School Libraries in the Picture, Web blog, Albano Terme, Padova: Edith Cowan University Research Online, 2009, pp. 1-12, Available from: http//ro.ecu.edu.au/cgi/viewcontent.cgi?article=1661\& context= ecuworks [Accessed 18th June 2015].

[2] A. J. A. M. Van Deursen, J. A. G. M. Van Dijk, O. Peters, "Rethinking internet skills:the contribution of gender, age, education, internet experience, and hours online to medium- and content-related internet skills," Poetics, vol. 39, pp. 125-144, 2011.

[3] M. Zimerman, "Digital native, searching behavior and the library," New Library World, vol. 113, pp. 174-201, 2012.

[4] A. Malliari, S. Korobili, S. Zapounidou, "Exploring the information seeking behavior of Greek graduate students: a case study set in the University of Macedonia," The International Information \& Library Review, vol. 43, pp. 7991, 2011

[5] D. O. Case, ed, "Looking for Information A Survey of Research on Information Seeking, Needs, and Behavior," 3rd ed, Bingley: Emerald Group, 2012.

\footnotetext{
The Information Seeking Behavior of Digital Native and Digital Immigrant... (Janti Gristinawati Sujana)
} 
[6] T. D. Wilson, "Models in information behaviour research," Web blog, 1999. Available from: http://informationr.net/tdw/publ/papers/1999JDoc.html [Accessed 26th September 2012].

[7] Irwanto, "Focused Group Discussion (FGD): Sebuah Pengantar Praktis," Jakarta: Yayasan Obor Indonesia, 2006.

[8] [APJII] Asosiasi Penyelenggara Jasa Internet Indonesia. Profil pengguna internet Indonesia 2014. Pusat Kajian Komunikasi Universitas Indonesia, ed. Web blog. Jakarta: APJII, 2015. Available from: http://ajidenpasar.or.id/asset/bankdata/Survey\%20APJII\%202014 \%20v3.pdf [Accessed 21st October 2016].

[9] M. Idrus, "Metode Penelitian Ilmu Sosial," ed ke-2, Jakarta: Erlangga, 2009.

[10] U. Sivarajah, Z. Irani, V. Weerakkody, "Evaluating the use and impact of Web 2.0 technologies in local government," Government Information Quarterly, vol. 32, pp. 473-487, 2015.

[11] D. Tapscott, "Grown Up Digital: yang Muda yang Mengubah Dunia,” Jakarta: Gramedia Pustaka Utama, 2009.

[12] S. Tury, L. Robinson, D. Bawden, "The Information seeking behaviour of distance learners a case study of the University of London International Programmes," The Journal of Academic Librarianship, vol. 41, pp. 312-321, 2015.

[13] R. Savolainen, "Approaches to socio-cultural barriers to information seeking," Library \& Information Science Research, vol. 38, pp. 52-59, 2016. 